
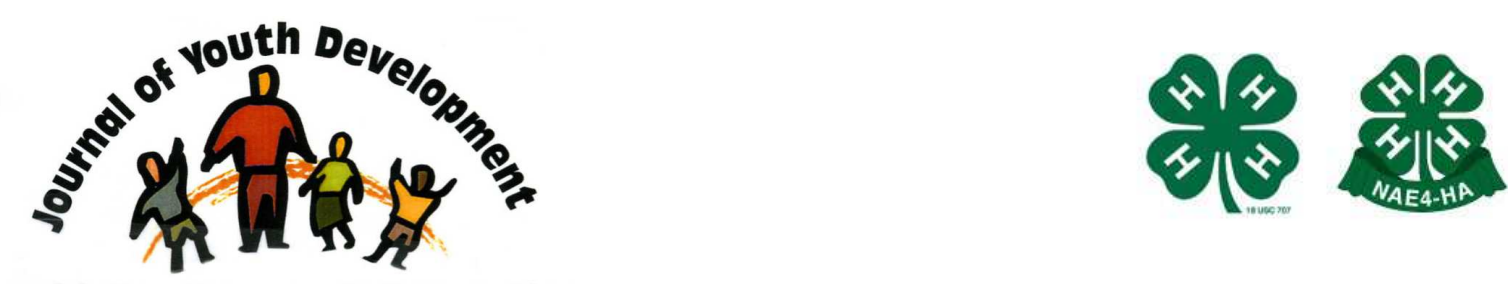

Bridging Research \& Practice

\title{
How ScienceQuest Ensures Success for All
}

\author{
Judith Zorfass \\ Education Development Center \\ Newton, MA \\ jzorfass@edc.org \\ Jennifer Dorsen \\ Education Development Center \\ Newton, MA \\ jdorsen@gmail.com \\ Caitlin Feeley \\ Education Development Center \\ Newton, MA \\ cfeeley@edc.org
}




\title{
JOURNAL OF YOUTH DEVELOPMENT \\ bridging research and practice
}

\section{How ScienceQuest Ensures Success for All}

\author{
Judith Zorfass, Jennifer Dorsen and Caitlin Feeley \\ Education Development Center
}

\begin{abstract}
Informal educational programs that reach out to minority youth in low-income urban areas need to anticipate diversity. Not only will participants exhibit a range of abilities and needs, but some, just like in any population, are likely to have learning disabilities. ScienceQuest, an informal science education program funded by the National Science Foundation, was designed to ensure that youth aged 10 to 14 with diverse abilities and needs, including learning disabilities, can successfully participate and succeed in inquiry-based learning. The program uses the I-Search curriculum as the basis of its inquiry process. Embedded in this curriculum are the following inclusive practices: youth are motivated to explore their topic; they use varied media that supports their learning styles; they are guided to process information through multiple means; and they have access to technology tools. These ongoing inclusive practices ensure that everyone successfully explores the world around them.
\end{abstract}

\section{Introduction}

NSTA (National Science Teachers Association) strongly supports and advocates for informal science education; it is seen as a way to complement, supplement, deepen, and enhance classroom science. NSTA shares a common mission and vision espoused by the National Science Education Standards (1999). One key element of the shared mission is that:

Informal science education allows for different learning styles and multiple intelligences and offers supplementary alternatives to science study for nontraditional and second language learners. It offers unique opportunities through field trips, field studies, overnight experiences, and special programs.

What does it take to translate vision into practice? What must informal science education programs do to meet the needs of its diverse participants? Education Development Center, 
Inc., with funding from the National Science Foundation, designed ScienceQuest, an informal science education program, to be inclusive from the outset. Participants, regardless of background, engaged in inquiry-based activities, worked together cooperatively, developed an understanding of science concepts, and built websites to share knowledge. The inclusive practices used within ScienceQuest provide a model for other programs seeking to ensure accessibility.

\section{Overview}

The National Science Foundation funded EDC of Newton, Massachusetts from 2000-2005 to design and implement ScienceQuest, an informal science education program for young adolescents between 10 and 14 years old from low-income urban settings. During this time ScienceQuest was implemented in over 100 sites-community technology centers, communitybased organizations such as Boys and Girls Clubs, YMCAs, and school-based programs around the country. The overall goal was to help young adolescents to develop science concepts through science explorations. It was designed to be equally accessible to youth with and without disabilities. Adult volunteer coaches met weekly with small teams of 3-5 young adolescents over approximately 15 weeks to explore a science topic selected by each team. Teams followed an I-Search curriculum which guides teams to work together collaboratively to acquire and apply inquiry-based skills to develop science knowledge. The culmination of the team's exploration was the design and launching of a website to share what they learned.

EDC designed ScienceQuest to ensure that the program would incorporate research-based inclusive practices (Fernandez, Green, Parker, \& Phelan, 2002; Haskell, 2000; McLaughlin, 2005). This was critical, given that the participants represented diverse abilities and needs, including learning disabilities. The I-Search curriculum (Zorfass, \& Copel, 1998) was the instructional framework for the ScienceQuest program. It not only helped to build science inquiry skills, but also naturally embedded inclusive practices (DiGisi, 2000; Scruggs, \& Mastropieri, 1994; Stainback, \& Stainback, 1996). Below we describe the inclusive practices in the I-Search.

\section{Inclusive Practices in the I-Search}

Originally used in formal education, the I-Search was adapted for the informal science education program of ScienceQuest (Zorfass, \& Dorsen, 2002). Four inclusive practices characterize the I-Search curriculum used in ScienceQuest:

Participants are guided through four phases of the inquiry process.

- They are motivated to explore questions of their choosing.

- They explore topics and gather information through varied media and experiences.

- They have multiple means for processing and expressing information.

- They use technology tools.

Below, we describe how these inclusive practices come alive in ScienceQuest. 


\section{Teams are Guided through Four Phases of the Inquiry Process}

Research indicates that students with disabilities, "at-risk" and "struggling" students, and second language learners benefit from clear direction about how to proceed and what the expectations are (Delpit, 1996). Responsive to this need, the I-Search process guides ScienceQuest participants through four distinct phases of exploration, as shown in Figure 1.

Figure 1

Phases of the I-Search Process
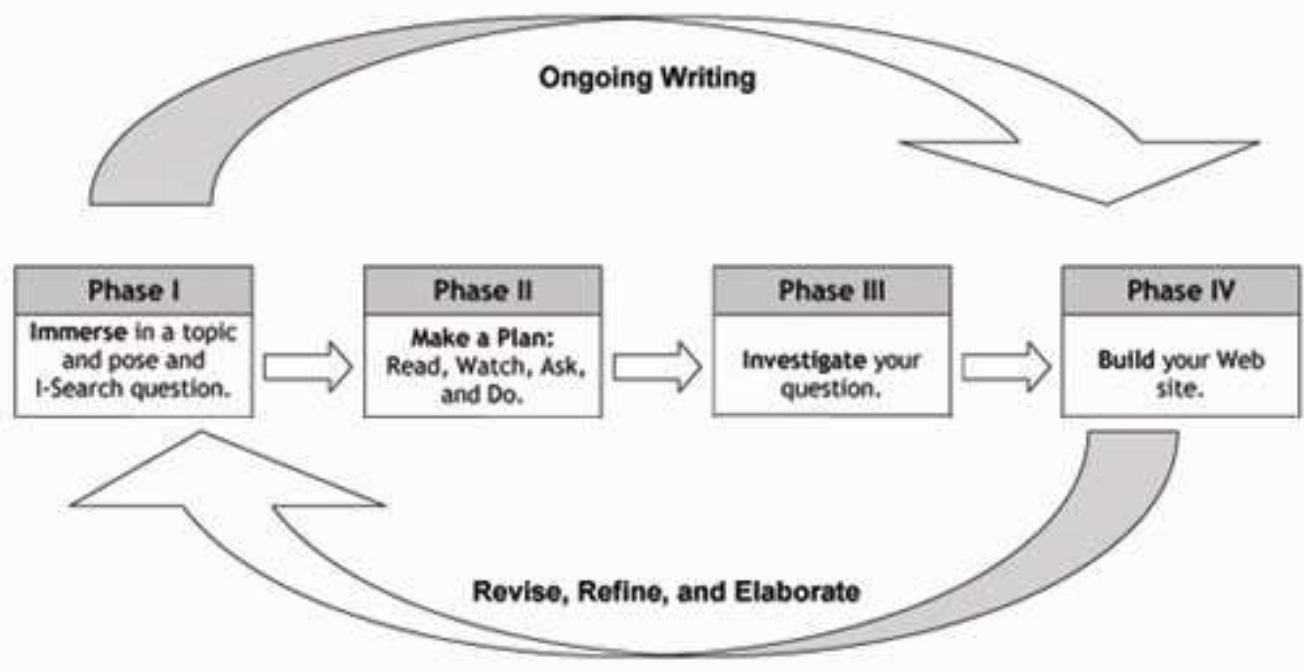

Each of the four steps of the I-Search has its own goal and set of activities.

- Phase 1: Immersion. The coach helps the ScienceQuest team explore varied topics by doing experiments, going on trips, talking to experts, and surfing the Internet. The goal is for teams to discover a search topic or question they feel passionate about.

- Phase 2: Making a Plan. The team decides how they will gather information by reading, watching, asking and doing.

- Phase 3: Gathering and Integrating Information. By implementing their plan, the team gathers information, analyzes it, and makes meaning.

- Phase 4: Sharing Knowledge. The team designs, builds and launches a website that describes the learning process and recounts the team's discoveries.

While the steps of the I-Search are concrete enough to be helpful, they also leave plenty of room for maneuverability, an important element of informal education. For example, once a team starts to gather information, they may decide to revise their question as some other topic becomes more intriguing. While developing their website, they may find the need to return to the information gathering mode to fill in emerging gaps. They are supported in this process with the structure of the I-Search.

\section{Teams are Motivated to Explore Questions of their Choosing}

Motivation plays a key role in learning, especially for young adolescents who struggle to learn. Guthrie and Davis (2003) advise educators to create opportunities for intrinsic motivation-the 
desire to learn for its own sake-by giving young adolescents a chance to become engaged and make choices about learning. Promoting motivation is a defining characteristic of the I-Search. In Macrorie's words, a quest for knowledge is like an "itch" that needs to be scratched (Macrorie, 1988, p. 100).

Through varied explorations during Phase 1: Immersion, the team members come to appreciate that science is all around us, and to see that their questions are fertile ground for explorations. At First Baptist CDC, in Somerset, NJ, a team of young adolescent boys created a project on bodybuilding with the help of local medical school students, learning about the biology of muscles in the process. Other teams have used roller coasters, asteroids, and chocolate as the jumping off point for explorations.

\section{Teams Explore Topics and Gather Information through Varied Media and Experiences}

Once the team selects a topic or question, the remaining phases of the I-Search process guide them to gather information through varied media and experiences. Four simple verbs capture a host of strategies for a productive search: read, watch, ask, and do.

- Reading: articles, text contained on Internet sites, posters, and magazines.

- Watching: videos, slides, TV shows, and Web-based simulations.

- Asking: questions of experts, conduct interviews, or write letters.

- Doing: carrying out experiments, building models, and going on field trips.

Encouraging the team to read, watch, ask, and do guarantees that participants with diverse abilities and needs will be able to pursue activities that align with their own learning styles, such as auditory, tactile, or visual. One team included a girl who used a wheelchair due to a neuromuscular disorder. When the team collaborated to build a papier-mâché model of the Solar System, they were involved in reading, watching, asking, and doing (Phase 3 activities). Each team member had a role to play. The girl who used a wheelchair helped read directions, ask experts for advice, or paste newspaper strips where she was able.

Through varied activities, the strengths that each team member brings can contribute to the success of the group. For instance, while one team was working on balloon cars to learn about the laws of motion, one twelve-year-old, "Mike," found it hard to focus, often interrupted others, and disrupted group activities with off-topic comments. Since Mike thrived on individual, technology-oriented work, he used the computer while the team brainstormed ideas to improve their balloon car model. Mike googled "balloon car," turning up a number of photos of different styles of cars, all of them radically different from their original design. The coach encouraged Mike to share his discovery with the team, weaving his discoveries back into the discussion. Group conversation, technology mediated experiences, images and opportunities to compare designs all contributed to Mike's success with the group (C. Feeley, personal communication, November 24, 2004).

\section{Teams Have Multiple Means of Processing and Expressing Information}

In Phase 3 of the I-Search, teams not only gather information, but also integrate it to build understanding. To be fully inclusive, the I-Search recommends that coaches use selected research-based instructional strategies, all of which are easily integrated into an informal 
learning program. Many strategies, such as using journals and graphic organizers, might already be familiar to program staff.

Having students keep a science journal is a recommended strategy for inquiry projects. They give students the opportunity to capture in writing not only a way to document the process they carried out, but also what they learned. Science journals are important tools for capturing the process of discovery and inquiry, as well as synthesizing new information (Dahl, \& Franzen, 1997; Yorks, 1996). As teams engage in activities, they are able to document what they did and what they learned, either in print or electronically. One team used journals that had prompting questions for note taking, for example: "describe one thing you learned today," or, "complete this sentence: I want to learn more about. . .." Journal-writing helped students record what they learned, while formulating more questions for investigation. For instance, one team member wrote in her journal about the "walk-about" from earlier that day: "I learned more about nature. That cats are small animals. Why can cats fit in small places? I wont to learn about it [sic]" (Figueroa, 2001). Having a written log allows the team to watch their process, relying on documentation to keep everyone up to date over the many weeks of the project. In this way, their learning is visible through the words on the page, and the team can more easily celebrate their progress.

Another effective strategy for learning supported by recent research is using paper or computer graphic organizers to organize information that might be abstract or complex to the youth (Gordon, 2002; IARE, 2003). Some teams used a web drawing on newsprint or information on index cards to show how they would organize their information. Graphic organizers also helped some teams to plan their multi-page websites.

\section{Teams Use Technology Tools}

There is a growing literature about the value of using low-, mid-, and high-tech tools to support the inclusion of students with disabilities (Woodward, \& Reith, 1997). From the beginning, EDC highlighted the use of technology within the I-Search as a way to improve success for youth with disabilities in inclusive settings (Zorfass, 1994).

- Low-tech tools can include sticky notes, highlighter pens, and raised-line paper to help with reading and writing. Some ScienceQuest teams used sticky notes to record ideas and then rearranged and reconnected them on newsprint into an ordered web of meaning.

- Mid-level tech tools include tape recorders for recording interviews and video cameras for documenting field trips.

- High-tech tools include computer-based software programs, such as word processing, or graphical organizers, such as Inspiration ${ }^{\mathrm{TM}}$.

The computer was the prime vehicle for sharing information in ScienceQuest, where each team built a website as a culminating activity. It is also important to note that youth who are traditionally marginalized and rarely have a chance to act as authorities or leaders at school can be particularly motivated by the opportunity to create a website that shares information for visitors, friends and adults. For example, a team of Hispanic youth in Boston worked twice as hard to ensure that their family members-some English speakers, some not-would have access to their findings on lions by creating a site that had all information in both English and Spanish. The power of seeing their finished websites on the Internet cannot be underestimated. 


\section{Conclusion}

The article above describes four different inclusive practices used in ScienceQuest. While each of these has been proven effective in its own right, when combined, they created powerful context for effective learning. Our findings can serve to help other programs who want to integrate inclusive practices to meet the needs of all of their participants. In considering how to translate our strategies into practice, they should consider the following: how and when the strategies will be used, either singly or in combination: the constellation of abilities and needs of their students; the knowledge and comfort level of the staff; and a team's access to resources. Our goal in writing this article was to encourage others to plan for diversity through the use of these and other inclusive practices.

\section{References}

Dahl, S., \& Franzen, P. (1997). The science journal: Writing and inquiry development. Sciencelines: A Newsletter From the Teacher Resource Center at Fermilab, Fall 1997. Retrieved January 4, 2008, from http://www.ed.fnal.gov/trc/sciencelines online/fall97/activity inserts.html

Delpit, L. (1996). Other people's children: Cultural conflict in the classroom. New York: New Press.

DiGisi, L. (2000). The action reflection process: Supporting all students in action-based science. Retrieved January 4, 2008, from http://www2.edc.org/arprocess/Imprana.htm

Fernandez, Y., Green, L., Parker, M., \& Phelan, M. (2002). Inclusion Project report. Retrieved January 4, 2008, from http://filebox.vt.edu/users/mphelan/electronicportfolio/TLP/inclusionincience.pdf

Figueroa, B. (2001). Unpublished ScienceQuest journal. July, 2001. Roslindale, MA: High Point Village CTC.

Gordon, C. (2002). Methods for measuring the influence of concept mapping on student information literacy. School Library Media Research (5). etrieved January 4, 2008, from http://www.ala.org/ala/aasl/aaslpubsandjournals/slmrb/slmrcontents/volume52002/gordon.cfm

Guthrie, J.T., \& Davis, M.H. (2003). Motivating struggling readers in middle school through an engagement model of classroom practice. Reading and Writing Quarterly, 19, 58-85.

Haskell, D. (2000). Building bridges between science and special education: Inclusion in the science classroom. Electronic Journal of Science Education, 4(3). Retrieved January 4, 2008, from http://unr.edu/homepage/crowther/ejse/haskell.html

Macrorie, K. (1988). The I-Search paper. Portsmouth, NH: Boynton/ Cook. 
McLaughlin, M. (2005). Accessing the general curriculum: Including students with disabilities in standards-based reform. housand Oaks, CA: Corwin Press.

NSTA. (1999). NSTA position statement: Informal science education. Retrieved January 4, 2008, from http://www.nsta.org/about/positions/informal.aspx .

The Institute for the Advancement of Research in Education (IARE) at AEL. (2003). Graphic organizers: A review of scientifically based research (executive summary). Charleston: AEL. Retrieved January 4, 2008, from http://www.inspiration.com/vlearning/research/index.cfm

Stainback, S., \& Stainback, W. (Eds.) (1996). Inclusion: A guide for educators. Baltimore: Paul H. Brookes.

Scruggs, T.E., \& Mastropieri, M.S. (1994). The construction of scientific knowledge by students with mild disabilities. The Journal of Special Education, 28(3), 307-321.

Woodward, J., \& Reith, H. (1997). A historical review of technology research in special education. Review of Educational Research, 67, 503-536. Retrieved December, 2006, from http://www.ldonline.org/ld indepth/research digest/sociodemographics.html

Yorks, K. (1996). Using dialogue journals in support of science instruction. In Periodic tableau: News from the 1996 Access Excellence Summit. Washington: Access Excellence. Retrieved January 4, 2008, from http://www.accessexcellence.org/MTC/96PT/Share/yorks.html

Zorfass, J. (1994). Supporting students with learning disabilities: Integrating technology into an I-Search unit. Technology and Disability, 3 (2), 129-136.

Zorfass, J., \& Copel, H. (1998). Helping middle school students become active reseachers. Alexandria, VA: Association for Supervision and Curriculum Development.

Zorfass, J., \& Dorsen, J. (2002). ScienceQuest: Literacy development within an informal science education initiative. Reading Online, March 2002. Retrieved January 4, 2008, from http://www.readingonline.org/articles/art index.asp?HREF=zorfass/index.html .

(C) Copyright of Journal of Youth Development Bridging Research and Practice. Content may not be copied or emailed to multiple sites or posted to a listserv without copyright holder's express written permission. Contact Editor at: patricia.dawson@oregonstate.edu for details. However, users may print, download or email articles for individual use.

ISSN 2325-4009 (Print); ISSN 2325-4017 (Online) 